ДВНЗ «Киӥвський напіональний економічний університет ім. Вадима Гетьмана»

Г. П. КУЛШШИ,

кандидат економічних наук, дочент кафедри корпоративних фінансів і контролінгу

ДВНЗ «Киёвський начіональний економічний університет ім. Вадима Гетьмана»

\title{
Система управління ефективністю діяльності підприємств, iї особливості та проблеми застосування в Україні
}

Стаття присвячена питанням, пов'язаним із особливостями використання концепції управліния ефективністю діяльності як прогресивного підходу до прийняття управлінських ріиень щодо покращення здатності компаній оцінювати свій фінансовий стан і підвищувати кінцевий фінансовий результат.

Ключові слова: управління ефективністю, комплексне управління якістю, управління за чілями, кількісні і якісні показники, індивідуальні та командні показники, фінансові та нефінансові показники, рівень ефективності, рейтинг працівника, ризики.

Постановка проблеми. Оцінка ефективності господарської діяльності та управлінських рішень, конкретних технологій їх забезпечення становить у сучасних умовах особливий інтерес як 3 наукової, так і $з$ практичної точки зору. Важливість методологічних розробок щодо побудови найбільш ефективних систем управління діяльністю підприємств, вибору адекватних для сучасних кризових умов методів управління обумовлює об'єктивну необхідність у систематизації та аналізі наявного досвіду застосування концепції управління ефективністю (Performance Management, PM). Оскільки РМ поєднує процеси управління компанією, методологію оцінювання іiі ефективності, набір показників ефективності, технологічні рішення і системи підтримки процесів, вона являє собою підхід до управління, спрямований на підвищення ефективності управління компанією та реалізації ії стратегії.

Використання РМ у практиці вітчизняних підприємств дозволить не лише визначати стратегічні цілі, а й оцінювати ефективність діяльності відносно цих цілей та управляти процесом їх досягнення.

Аналіз останніх досліджень і публікацій. Аналізу особливостей використання концепції РМ присвячені праці іноземних та вітчизняних науковців. Значний внесок у дослідженні цих проблем зробили Обрі К. Даніелсон, Ханс де Брюйн, Анджела Барон, Майкл Армстронг. Окремі напрямки системи РМ розглядали в своїх роботах А. Гольда, В. Захарченко, О. Кулагін, А. Ніц, І. Чернишова. Але наявні теоретичні розробки не дають відповіді на питання щодо вибору найбільш ефективних методів управління бізнесом з урахуванням організації і стимулювання діяльності працівників для досягнення поставлених цілей.

Мета роботи - визначити особливості оцінювання результативності діяльності підприємства в сучасних умовах, розкрити сутність і класифікацію основних систем оцінювання результативності діяльності підприємства та механізму їх впровадження, обгрунту вати вплив системи РМ на компанію в цілому і можливості іiі впровадження в Україні.

Виклад основного матеріалу дослідження. Система РМ спрямована на покращення здатності підприємства оцінювати можливості щодо подальшого розвитку, моделювати фактори, що впливають на досягнення поставлених цілей; здійснювати

(C) В. З. Потій, Г. П. Куліш, 2017 
моніторинг показників ефективності та визначати їх відхилення від запланованих; складати управлінську і фінансову звітність, яка допомагає приймати економічно обгрунтовані стратегічні рішення [1].

В цій системі управління виділяють два основні підходи. Перший підхід стосується комплексного управління якістю і пов'язаний з управлінськими діями щодо діяльності працівників “знизу вгору". Другий підхід - це управління за цілями. Він пов'язаний iз чітким визначенням завдань підприємства, орієнтованих не на слабкі, а на сильні сторони діяльності кожного працівника і підприємства в цілому. Цей підхід вимагає визначення чітких параметрів оцінювання якості і індивідуальної роботи кожного працівника [2].

Отже, систему РМ доцільно розглядати як один зі способів підвищення ефективності роботи кожного працівника i, в кінцевому результаті, - підвищення продуктивності праці.

Визначення результативності діяльності працівника може здійснюватись через ключові показники діяльності (Key Performance Indicators, KPI). Нерідко у літературі KPI трактують як всеохоплюючу систему оцінювання, шо забезпечує досягнення оперативних і стратегічних цілей. На основі набору показників цієї методики зазвичай будується система мотивації та стимулювання співробітників. Тобто КPI - це специфічна область системи контролінгу компанії. Тому потрібно розуміти, що КРІ $є$ допоміжним інструментом, який використовують для досягнення певних цілей. Якщо результативність діяльності працівника знижується, то відповідно знижується і винагорода.

Поставлені цілі повинні бути пов'язані з результатами їх досягнення; основані на кількісних показниках (співвідношеннях). Крім того, вони мають бути досяжними і виконуватись у межах визначеного часу [3].

Застосування системи РМ передбачає використання різних показників: кількісних і якісних, індивідуальних та командних, фінансових та нефінансових.

Кількісні показники - це показники, що мають економічний або фізичний зміст (гривні, тонни, штуки, частки і т. д. ). Якісні - бали, що відповідають рівню досягнення результату (якість документообороту, дотримання трудової дисципліни та ін.).

Індивідуальні показники обумовлені результатами, які залежать тільки від зусиль конкретного працівника (кількість укладених договорів, частка бракованих виробів, вироблених працівником).

Командні показники відображають підсумки діяльності структурного підрозділу. Вони залежать від зусиль різних працівників і стимулюють їх до ефективної внутрішньокорпоративної праці.

Фінансові показники пов'язані з фінансовими результатами діяльності підприємства, його структурного підрозділу або працівника (рентабельність продажів, коефіцієнт оборотності активів, маржинальна рентабельність, чистий прибуток, грошовий потік та ін.).

Нефінансові показники відображають ринкове становище компанії і ефективність внутрішніх бізнес-процесів (частка ринку, продуктивність праці, тривалість виробничого циклу, рівень конкурентних переваг, виконання плану розвитку підприємства та ін.).

3 метою оцінювання результатів діяльності працівників компанії застосовують не всі можливі KPI, а лише ті, що забезпечують виконання найбільш важливих результатів роботи у певний період [4].

Результати проведеного дослідження показують, що в діяльності підприємств доцільно визначати три рівні ефективності:

1. Неприпустимий рівень. Це так звана “нульова точка", з якої починається відлік результату. Таким, наприклад, у фахівців відділу продажів може вважатись показник "обсяг продажів", рівний 500 тис. грн, і суми менше цього рівня розглядатимуться як відсутність результату. Так само $\mathrm{i}$ для інших аналогічних показників. А для КРІ, значення яких бажано зменшувати (наприклад, частка виробничого браку, транспортні витрати та інше), база встановлює максимальний поріг зміни цього показника.

2. Нормативний рівень - повинен обов'язково бути досягнутий, незважаючи на ситуацію на ринку, складності роботи, можливості співробітника. Він може 
бути задовільним або достатнім. Нормативним рівнем вважається стовідсотковий результат діяльності.

3. Наднормативний рівень - це рівень ефективності, до якого потрібно прагнути. Він необхідний для того, щоб орієнтувати і мотивувати працівників на пошук додаткових ресурсів і прихованих резервів для досягнення високих результатів. Значення нормативного і наднормативного рівня можуть збігатися, коли це найкращі значення показника (наприклад, обсяг виробництва за визначених умов), або ж перевиконання норми позбавлене сенсу (наприклад, коефіцієнт оборотності кредиторської заборгованості).

Фактичні якісні значення КРІ оцінюються в балах після закінчення звітного періоду (місяця, кварталу). Доволі часто в РМ для оцінювання якісних показникків використовують бальні шкали 3 кількістю балів від 5 до 7. Наприклад, 1 - неприйнятний результат, 2 - посередній, 3 - нормальний (достатній), 4 - відмінний, 5 - видатний. Однак у такому вигляді з оцінками показників не можна здійснювати арифметичні дії, оскільки значення порядкових шкал не показують ступінь відмінності оцінок, а демонструють лише факт переваги одного об'єкта перед іншим. 3 метою подолання цієї проблеми для оцінювання якісних КРІ використовується "квазіметрична" 100-бальна шкала. На iї основі можна гнучко підходити до встановлення “опорних точок" для якісних КРІ, наприклад: неприпустимий рівень - від 0 до 20, нормативний рівень - від 40 до 60 , наднормативний - від 80 до 100 балів. Але тлумачення балів має бути однозначним, щоб працівники розуміли, яких результатів від них очікують внутрішні користувачі і які будуть наслідки. Після отримання фактичного значення певного КРІ визначається відносний результат роботи за цим КРІ, і отриманий результат відображає ступінь виконання або перевиконання нормативного рівня.

Представлену методику доречно використовувати і для КРІ, значення яких бажано зменшувати. Оскільки вона дозволяе перевести значення всіх КРІ (незалежно від їх змісту) в єдину шкалу для подальшого оцінювання результативності різних працівників за ступенем виконання (у відсотках) встановлених нормативних вимог.

Після отримання оцінки кожного показника можна визначити загальний результат (рейтинг) працівника. Для досягнення цієї мети окремі результати результати (у відсотках) множаться на вагу відповідних КРI і складаються. В результаті розраховується “середньозважений" коефіцієнт, який відображає загальну результативність співробітника з урахуванням важливості і фактично отриманих значень всіх його КРI. Якщо отриманий коефіцієнт більше $100 \%$, це свідчить про високу результативність працівника (вище встановленої норми). В подальшому оцінка загальних результатів може використовуватися для ранжування та преміювання співробітників компанії.

Такий підхід мотивує співробітників компанії до підвищення ефективності роботи і розвитку ключових професійних якостей, що в подальшому сприяє досягненню ними необхідних результатів.

Отже, використання методології РМ дозволяє оцінити показники діяльності підприємства та управляти ними; передбачати інтеграцію процесів стратегічного, операційного, фінансового управління та управління ризиками. Ця методологія також надає можливість порівняння результатів у сфері економічного управління на підприємствах, отриманих для України, із загальносвітовими тенденщіями.

Компанією PwC Global Website Enquiries в 2012 р. проведено і оприлюднено результати дослідження щодо стану випровадження та використання методології концепції РМ українськими і російськими підприємствами (табл. 1).

Таблиця 1

\section{Стан впровадження та використання}

\section{Enterprise Performance Management в Україні і Pociï}

\begin{tabular}{|c|l|c|c|}
\hline \multicolumn{2}{|c|}{ Параметри системи управління } & Україна, \% & РФ, \% \\
\hline 1 & $\begin{array}{l}\text { Кількість компаній, які визнають важливість і необхід- } \\
\text { ність розроблення стратегії }\end{array}$ & 25 & 80 \\
\hline 2 & $\begin{array}{l}\text { Кількість компаній, які надають працівникам точну } \\
\text { iнформацію про стратегію на всіх рівнях організації }\end{array}$ & 52,5 & 80 \\
\hline
\end{tabular}


Продовження табл. 1

\begin{tabular}{|c|l|c|c|}
\hline \multicolumn{2}{|c|}{ Параметри системи управління } & Україна, \% & PФ, \% \\
\hline 3 & $\begin{array}{l}\text { Кількість компаній, які оцінюють інтеграцію процесів } \\
\text { стратегічного планування і бюджетування (повну або } \\
\text { майже повну) }\end{array}$ & 23 & 70 \\
\hline 4 & $\begin{array}{l}\text { Кількість компаній, які при формуванні бюджетів та } \\
\text { підготовці управлінської звітності використовують } \\
\text { принципи, наближені до МСФ3 }\end{array}$ & 28 & 70 \\
\hline 5 & $\begin{array}{l}\text { Кількість компаній, які визнають важливість автома- } \\
\text { тизації процесів збирання та оброблення інформації та } \\
\text { інтеграції ІТ-систем }\end{array}$ & 46,5 & 80 \\
\hline 6 & $\begin{array}{l}\text { Кількість компаній, які за останні два роки впровадили } \\
\text { зміни, що дозволяють підвищити достовірність і } \\
\text { своєчасність інформації }\end{array}$ & 46,5 & 76 \\
\hline 7 & $\begin{array}{l}\text { Кількість компаній, які використовують програми } \\
\text { короткострокової винагороди }\end{array}$ & 35 & 60 \\
\hline 8 & $\begin{array}{l}\text { Кількість компаній, які проводять щорічну оцінку } \\
\text { персоналу, основану на досягненні ключових показників } \\
\text { діяльності }\end{array}$ & 40 & 50 \\
\hline
\end{tabular}

Джерело: [5]

Дані анкетування українсыких та російсыких респондентів доводять відставання практики та інструментарію менеджменту вітчизняних підприсмств від стану сучасних вимог економічного управління в Росії. Розбіжності у менеджменті між Україною та Росією насамперед полягають у визнанні компаніями важливості і необхідності розроблення стратегії (25\% респондентів в Україні і $80 \%$ в Росіi), забезпечення інтеграції процесів стратегічного планування і бюджетування $(23 \%$ і $70 \%)$, надання співробітникам інформації про стратегію на всіх рівнях організації $(52,5 \%$ та 80\%), стимулювання персоналу з використанням ключових показників діяльності, які взаємопов'язані зі стратегією діяльності підприємства (40\% та 60\%).

Результативність та ефективність управління, на думку респондентів, залежить від принципів управління, які формуються під впливом системи пріоритетів та цінностей, що склалися у внутрішньому середовищі підприємства, оскільки вони дозволяють узгодити та скоординувати економічні процеси, забезпечити вибір адекватних методів економічного управління.

Як доводить проведений аналіз, для якісного функціонування системи РМ у вітчизняних (компаніях необхідно:

1. Всебічно обгрунтувати доцільність їі впровадження. Якщо діяльність компанії $€$ успішною, то перевага від ії впровадження в основному полягатиме в структуризації і систематизації того, з чим компанія працювала раніше.

2. Використовуючи комплекс інструментів РМ, не лише прогнозувати майбутні результати компанії, а й контролювати рівень фактичних результатів, поетапно управляти виконанням поставлених цільових орієнтирів, постійно проводити моніторинг фактичних результатів.

3. Орієнтуватися на перспективу. Бізнес може бути успішним із причин, які не залежать від сьогоднішніх рішень і технологій (кон'юнктура ринку, низький рівень конкуренції, доступ до дешевих ресурсів, монопольне становище на ринку тощо). Але за будь-яких умов важливо вміти управляти показниками ефективності, які забезпечують конкурентні переваги в перспективі, особливо коли в компанії знижується результативність

Підвищення конкурентоспроможності компанії на ринку в складних економічних умовах і при стрімкому падінні результативності ії діяльності вимагає негайного впровадження системи управління ефективністю. Разом із тим, впровадження РМ, як і будь-якої іншої управлінської технології, супроводжується ризиками, такими як 
недосконало побудована система управління; невірно обрані критерії оцінювання результативності і шкала оцінювання за обраними критеріями.

Слід відмітити, що жодна технологія управління сама по собі не здатна призвести до значних перетворень в компанії. І причина не в самій технології, а в ієрархії очікувань керівника від ії впровадження, оскільки управління ефективністю на підприємстві передбачає структурування процесів, які вже існують у компанії, тобто використання як колишніх ії напрацювань, так і нових технологій.

Висновки. Система РМ спрямована на поліпшення здатності підприємства оцінювати свій стан і управляти ефективністю діяльності на всіх рівнях у рамках загального інтегрованого середовища управління, враховуючи чинник мотивації працівників. Оцінка персоналу, основана на поєднанні оцінки КРІ і компетенцій, має стати одним з основних мотивуючих чинників для співробітників компаніі.

1. Діяльність персоналу за системою РМ не тільки сприяє підвищенню прибутків і ефективності роботи компанії, а й впливає на розвиток професійних якостей працівників, які забезпечують досягнення необхідних результатів.

2. Для бізнесу важливо бути успішним не тільки в поточному, а й у довгостроковому періоді. А для цього важливо удосконалювати управління показниками результативності та ефективності.

\section{Список використаних джерел}

1. Армстронг М., Барон A. Performance Management. Управление эффективностью работы. Hippo Publishing Ltd.,2007. 384 c.

2. Чернишова І. Принципи формування культури стійкої результативності в компанії [Електронний ресурc]. URL: URL: www.tmi.com.ua/ru/opinion/6.html.

3. Кулагин О. Как оценивать выполнение KPI по системе Performance Management? [Электронный ресурc]. URL: http://www.e-xecutive.ru/career/hr-management/1455763kak-ocenivat-vypolnenie-kpi-posisteme-performance-management.

4. Захарченко В. Система мотивации на основе КРI // Финансовый директор. 2006. № 2, С. 51-57.

5. Результати опитування керівників PwC Global Website Enquiries. URL: http://www. pwc.com $/ g x / e n / b l o g s . h t m l$

B. 3. ПОТИЙ, кандидат экономических наук, профессор кафедры корпоративных финансов и контроллинга,

ГВУЗ «Киевский нацииональный экономический университет им. Вадима Гетьмана»

А. П. КУЛИШ,

кандидат экономических наук, дочент кафедры корпоративных финансов и контроллинга,

ГВУЗ «Киевский национальный экономический университет им. Вадима Гетьмана»

\section{Система управления эффективностью деятельности предприятий, ее особенности и проблемы внедрения в Украине}

Статья посвящена вопросам, связанным с особенностями использования концепции управления эффективностью деятельности как эффективного подхода к принятию управленческих решений, направленных на улучиение способности компании оченивать свое финансовое состояние и повыиать конечный финансовый результат.

Ключевые слова: управление эффективностью, комплексное управление качеством, управление в соответствии с иелями, количественные и качественные показатели, индивидуальные и командные показатели, финансовые и нефинансовые показатели, уровень эффективности, рейтинг работника, риски. 
V. Z. POTIY,

PhD in Economics,

Professor of Corporate Finance and Controlling Department,

Kyiv National Economics University named after Vadym Hetman H. P. KULISH,

PhD in Economics,

Associate Professor, of Corporate Finance and Controlling Departament, Kiev National Economics University named after Vadym Hetman

\section{Performance Management System of the Company, It's Peculiarities and Problems of Application in Ukraine}

Performance Management (PM) at company level is concerned with actions to achieve formulated goals. PM refers to the strategic and comprehensive approach to enhance the company performance. The article's objective is to outline the specifics of performance assessment at company level, highlight the essence and classification of main systems for company performance assessment and their implementation mechanisms, determine the PM impact on a company and PM application possibilities in Ukraine. The PM algorithm and capabilities are analyzed. The following conclusions are made:

1. PMis designed to enhance the companies ' capabilities for performance assessment and management at all the levels within the integrated management environment with due consideration to the factor of employees motivation. The assessment of company personnel, based on combination of Key Performance Indicators (KPI) and competencies, has to be an essential motivating factor for the company employees.

2. Work of the company personnel by PM, apart from the increasing profit and performance, has positive implications for their professional qualities.

3. As a company needs to be successful not only in the current period, but in the long run, it is supposed to improve its PM.

Keywords: performance management, quality management, management by objectives, quantitative and qualitative indicators, individual and team indicators, financial and nonfinancial indicators, performance level; employee 's rank, risks.

Посилання на статтю:

Потій В. 3., Куліш Г. П. Система управління ефективністю діяльності підприємств, ii особливості та проблеми застосування в Україні // Науковий вісник Національної академії статистики, обліку та аудиту: зб. наук. праць. 2017. №1-2. С. 54-59. 